\title{
Herpes virus infection associated with interstitial nephritis in a beaked whale (Mesoplodon densirostris)
}

\author{
Manuel Arbelo ${ }^{1}$, Edwige N Bellière ${ }^{2}$, Eva Sierra ${ }^{1}$, Simona Sacchinni ${ }^{1}$, Fernando Esperón ${ }^{2}$, Marisa Andrada $^{1}$, \\ Miguel Rivero ${ }^{1}$, Josue Diaz-Delgado ${ }^{1}$ and Antonio Fernández ${ }^{1 *}$
}

\begin{abstract}
Background: The capacity for herpesvirus to cause disease in cetaceans is unclear and may be varied depending on the different conditions of individuals and between different species. Kidney pathology and intralesional virus-associated infection have been rarely reported in cetaceans.

Result: On April 2004, an old adult male Blainville's beaked whale (Mesoplodon densirostris) $420 \mathrm{~cm}$ long with a poor body condition was stranded on Tenerife Island. During necropsy, no gross lesions were observed in the kidneys. However, membranous glomerulonephritis, multifocal interstitial lymphoplasmacytic nephritis and acute multifocal necrotizing tubulointerstitial nephritis with intranuclear inclusion bodies was diagnosed by histological analysis. Tissue samples were submitted for bacteriological analysis and molecular viral screening.

Conclusion: A novel alpha herpesvirus associated with interstitial nephritis was identified in an old adult male Blainville's beaked whale ( $M$. densirostris) with a poor body condition stranded in the Canary Islands. This report suggests that identification of herpesvirus infection could be used as a differential diagnosis for interstitial nephritis in cetaceans.
\end{abstract}

Keywords: Beaked whale, Interstitial nephritis, Alpha herpes virus, Diagnosis

\section{Background}

The presence of herpesviruses (HV) in cetaceans was shown in the late 1980s by electron microscopy (EM) analysis demonstrating HV-like particles in skin biopsies from beluga whales (Delphinapterus leucas) [1,2]. EM analysis also demonstrated that HV was associated with encephalitis in a harbor porpoise (Phocoena phocoena) [3] and with skin lesions of dusky dolphins (Lagenorhynchus obscures) [4]. In addition to EM, immunoperoxidase staining [3], serum neutralization and enzyme-labeled immunosorbent assays have been used as indicators for the presence of $\mathrm{HV}$ in cetaceans [5]. Alpha-HV have been associated with fatal systemic infections in bottlenose dolphins (Tursiops truncatus) [6], a Cuvier's beaked whale (Ziphius cavirostris) [7], and with cutaneous lesions in bottlenose dolphins

\footnotetext{
* Correspondence: afernandez@dmor.ulpgc.es

${ }^{1}$ Unit of Veterinary Histology and Pathology, Institute for Animal Health (IUSA), Veterinary School, University of Las Palmas de Gran Canaria, Canary Islands, Spain

Full list of author information is available at the end of the article
}

[8]. Gamma-HV have been identified in mucosal lesions in bottlenose dolphins, Risso's dolphins (Grampus griseus), dwarf sperm whales (Kogia sima) and Blainville's beaked whales (Mesoplodon densirostris) [8-10].

The capacity of $\mathrm{HV}$ to cause disease in cetaceans is unclear and may show variations depending on the different conditions between individuals or within species [7-10]. Recently, systemic herpes viral lesions have been reported in a striped dolphin, likely secondary to the immunosuppression caused by morbillivirus co-infection [11].

Tubulointerstitial nephritis is characterized by inflammatory and degenerative changes in tubular epithelium associated with interstitial lymphoplasmacytic cell infiltration [12]. Interstitial lymphoplasmacytic nephritis is a frequent histopathological finding in cetaceans. However, intralesional etiologies or pathogenic virus or bacteria have rarely been associated with this type of lesion. Here we report the presence of tubulointerstitial nephritis in a

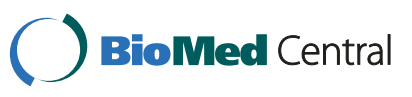


beaked whale stranded in the Canary Islands caused by a novel cetacean cytopathogenic alpha-HV.

\section{Methods}

On April 18th, 2004, an old adult male Mesoplodon densirostris (420 cm long) with a poor body condition was observed to be alive near the shore on Tenerife Island (Granadilla de Abona, Geographic Universal Trasverse Mercator (UTM) coordinate system, X 348338, Y 3102515). The whale died soon after beaching (Figure 1). Necropsy was started 8 hours postmortem (code 1-2) [13].

Routine sampling for histological, EM, immunohistological, bacteriological and virological studies were performed [7]. Samples fixed in $10 \%$ neutral buffered formalin were routinely processed and embedded in paraffin blocks. Histological sections were stained using hematoxylin and eosin (H\&E) as well as periodic acid Schiff (PAS). Additionally, immunohistochemistry (IHC) for the detection of morbillivirus and HV antigens was performed as previously described $[14,15]$ Tissue samples from lung, liver and kidney were submitted for bacteriological analysis $[7,13]$.

For molecular viral screening, $0.5 \mathrm{~g}$ of frozen tissues samples from skin, liver, muscle, lung and kidney were macerated in $4.5 \mathrm{ml}$ of phosphate buffered saline (PBS), using an automatic homogenizer (Precellys ${ }^{\circledR} 24$ Dual homogenizer, Bertin Technologies, Montigny le Bretonneux, France), and total nucleic acid was extracted by pressure filtration (QuickGene DNA tissue kit S, FujiFilm Life Science, Tokyo, Japan), following the manufacturer's instructions.

HV DNA detection was conducted by pan nested HV PCR [16] involving DFA, KG1 and ILK primers in the external PCR, and TGV-IYG primers in the internal PCR. The primer sequences have been described previously [16]. To determine positive samples, direct sequencing of the nested PCR product, approximately 220 base pairs (bp) was performed using the primers TGVseq - IYGseq.
To obtain additional nucleotide sequences (approximately $700 \mathrm{bp}$ in length), products of the external PCR from positive samples were amplified using the primers DFA and KG1. Amplified DNA fragments of the predicted size were purified and cloned into the plasmid vector pGEM-T (Promega Corporation) following the manufacturer's instructions and sequenced with the corresponding T7 primer (forward) and SP6 primer (reverse).

Two clones for each sample were selected. Once the consensus nucleotide sequence was obtained and the primer binding sites excluded, the Clustal W option in MEGA 4.0 was used to deduce the corresponding amino acid sequence and to construct an unrooted neighbor-joining tree. All the available cetacean HV DNA-polymerase gene sequences reported to date [6-11,17-20] were compared by their aminoacid (aa) sequences in the GenBank database, which is the recommended method for molecular HV classification [21].

Sequences that were 100\% identical were excluded (in those cases, only the sequence published first was conserved in the phylogenetic tree) and other sequences from HVassigned species available at the International Committee on Taxonomy of Viruses [22] were also included in the comparison.

\section{Result}

\section{Pathological findings}

Gross examination revealed several Xenobalanus $s p$ barnacles attached to the fluke, multiple cutaneous scars and atrophy of the epaxial musculature. Intravascular gas was noted within the epicardial, mesenteric and portal veins as well as beneath the liver capsule. Nematodes were observed within the bronchi. Fish bones, otoliths and plastic foreign debris were found within the squamous stomach. Many parasitic cysts (Phyllobothrium sp.) were observed in the retroperitoneal area as well as in

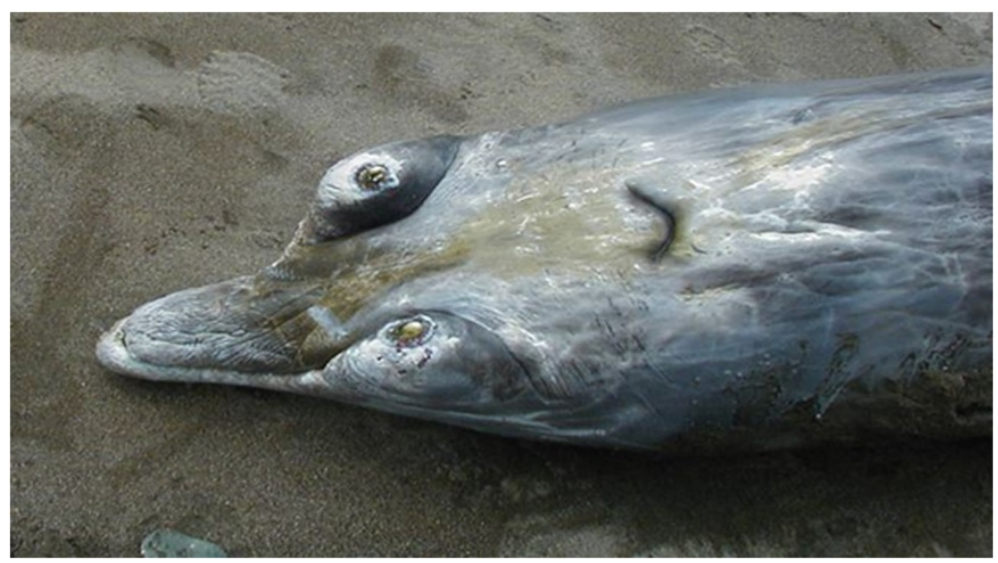

Figure 1 Stranded specimen involved. An adult old male Blainville's beaked whale (Mesoplodon densirostris). Mandibule and tooth features match with an old male beaked whale. 


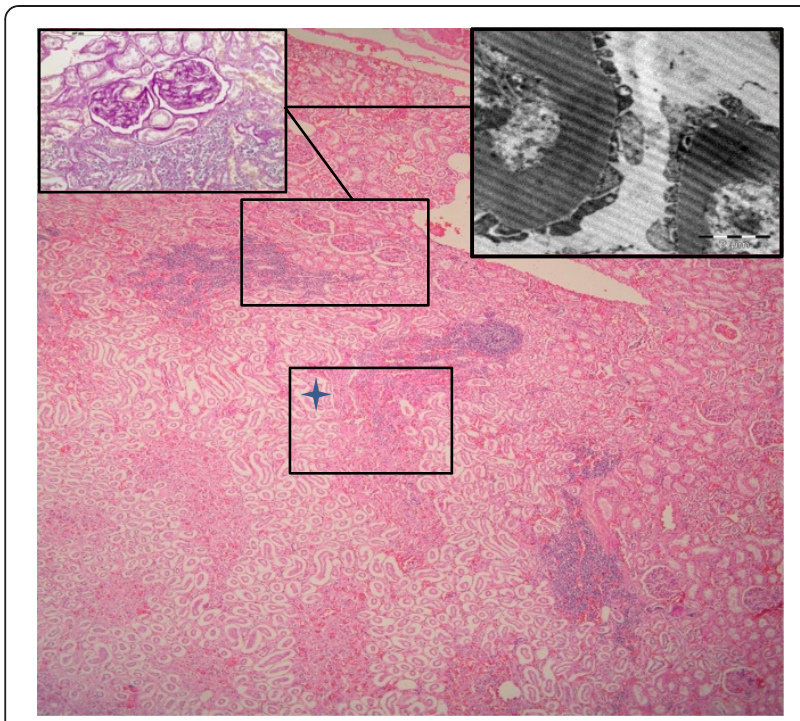

Figure 2 Histological, histochemical and ultrastructural findings. Kidney. Cortico- medular area of one reniculum. Multifocal lymphoplamacytic interstitial nephritis. H\&E (100X, bar=200 um). Up right side inset: Higher magnification of renal cortical area showing aggregate of lymphoplasmocytic cells and two glomeruli with (PAS positive). PAS technique (400x, barr= $100 \mu \mathrm{m})$. Up right side inset: EM picture showing thickening of glomerular basement membranes. (Bar $2 \mu \mathrm{m}$, EM technique).

testicular serosa. The kidneys were congested and no urine was found in the bladder.

Histologically, membranous glomerulonephritis was the main finding in the glomeruli (Figure 2, insets). A multifocal lymphoplasmacytic interstitial nephritis was present in 33\% of the reniculi by microscopic analysis (Figure 2). Multifocal interstitial and tubuloepithelial necrosis with the presence of intranuclear inclusion bodies in tubuloepithelial cells was observed (Figure 3) in the reniculi, which also presented with membranous glomerulonephritis and lymphoplasmacytic interstitial nephritis. Additional findings included intravascular non-staining vacuoles (gas-like bubbles) in the hepatic sinusoids, pericardial vessels, within small vessels of intestinal serosa and inter-renicular venous vessels. Mild multifocal parasitic bronchopneumonia with intraluminal nematodes was noted. Moderate diffuse intracytoplasmic eosinophilic globules were present in the hepatocytes, as frequently seen in active (alive) stranded dolphins (personal observation). Cortico-adrenal steatosis and multifocal lymphoplasmacytic adrenalitis were observed in both adrenal glands but no cell necrosis and/or viral inclusion bodies was found. Signs of testicular atrophy, likely associated with senescence, were observed with increased interstitial connective tissue and thickened basement membrane surrounding the atrophied tubules with no luminal spermatozoa.

\section{Immunohistological and ultrastructural study}

HV antigen was only detected in the kidney and immunopositivity was clearly observed in the intranuclear inclusions bodies of tubuloepithelial cells and small amount was associated with cell debris in necrotic areas. (Figure 3, inset). Ultrastructural analysis demonstrated that intranuclear inclusion bodies labeled immunohistologically corresponded to HV particles (Figure 3, inset).

\section{Bacteriological analysis}

Photobacterium damsela and Pasteurella skyensis were isolated from lung samples. Clostridium $s p$ was isolated from the liver. No bacteria were isolated from kidney samples.

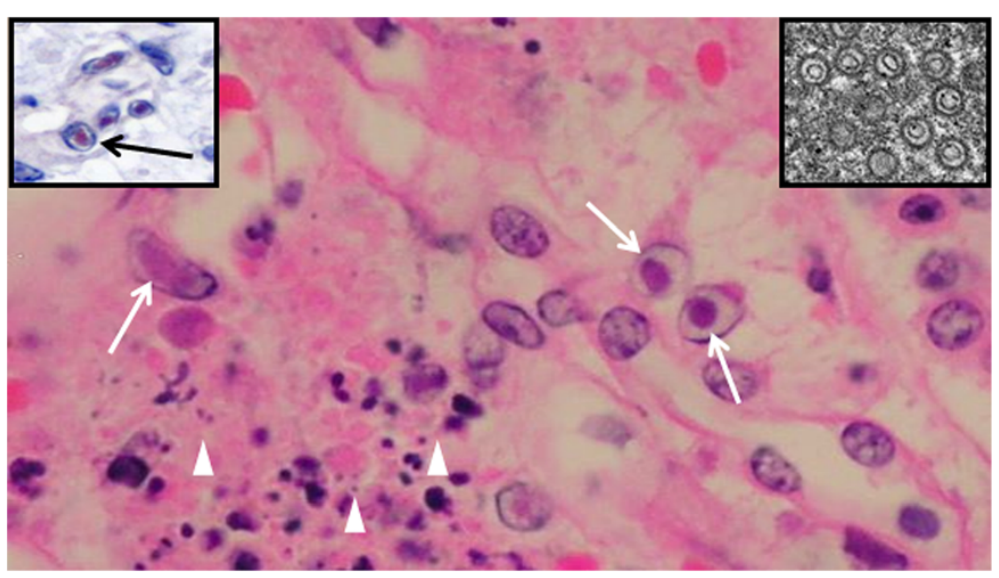

Figure 3 Immunohistological and ultrastructural interstitial kidney findings. Kidney. Higher magnification of Figure 2 (box with star). Interstitial cell necrosis (arrowheads) and intranuclear inclusion bodies (arrows) in tubuloepithelial cells. H\&E (bar=10 $\mu$ m). Inset up right: Herpes virus particles (EM) (bar=10 nm). Inset up left: Inclusion bodies labeled immunpositivelly for herpesvirus antigen (red colour) (arrow). IHC counterstaining with hematoxilin (bar=10 $\mu \mathrm{m})$. 


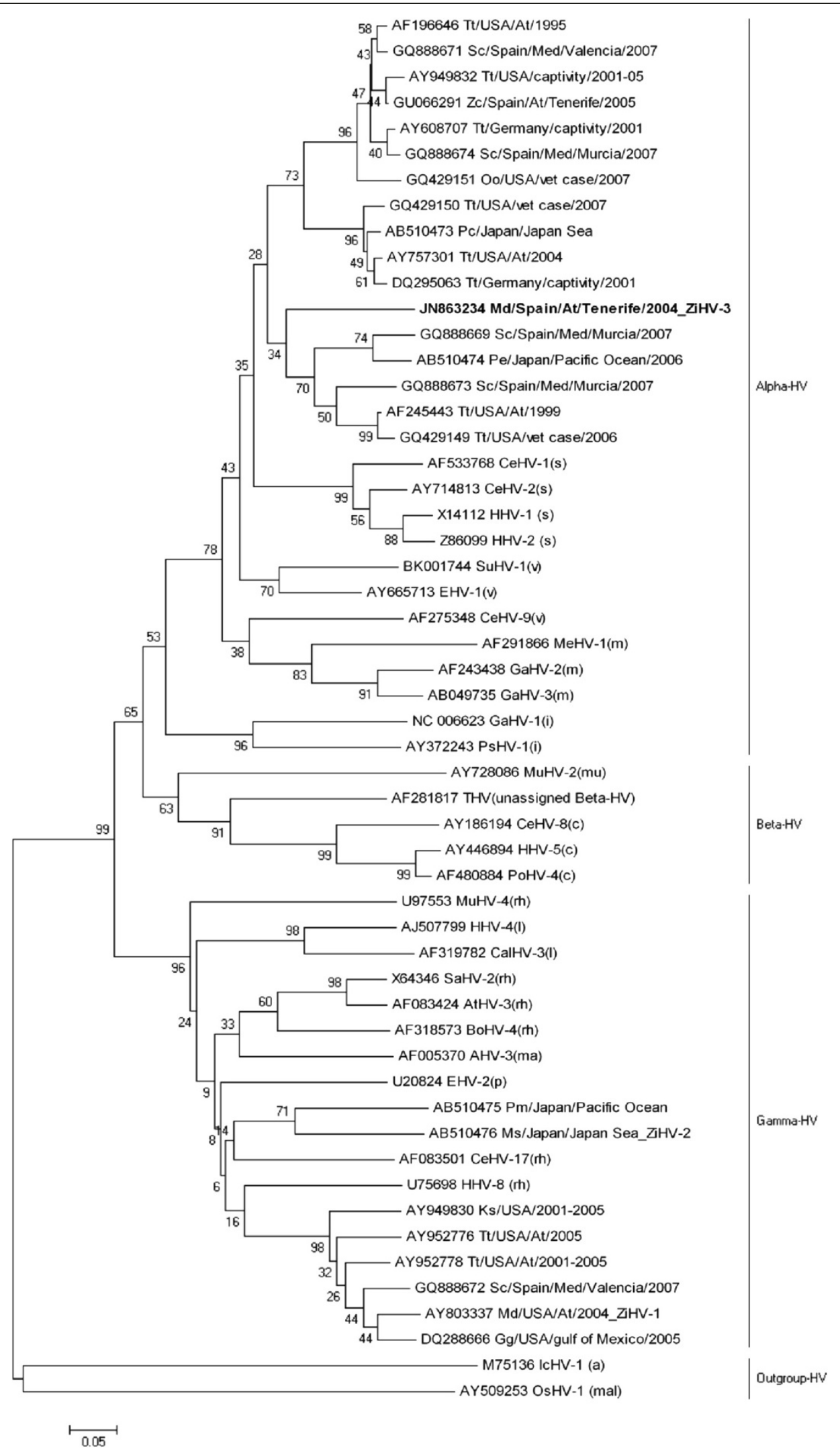

Figure 4 (See legend on next page.) 


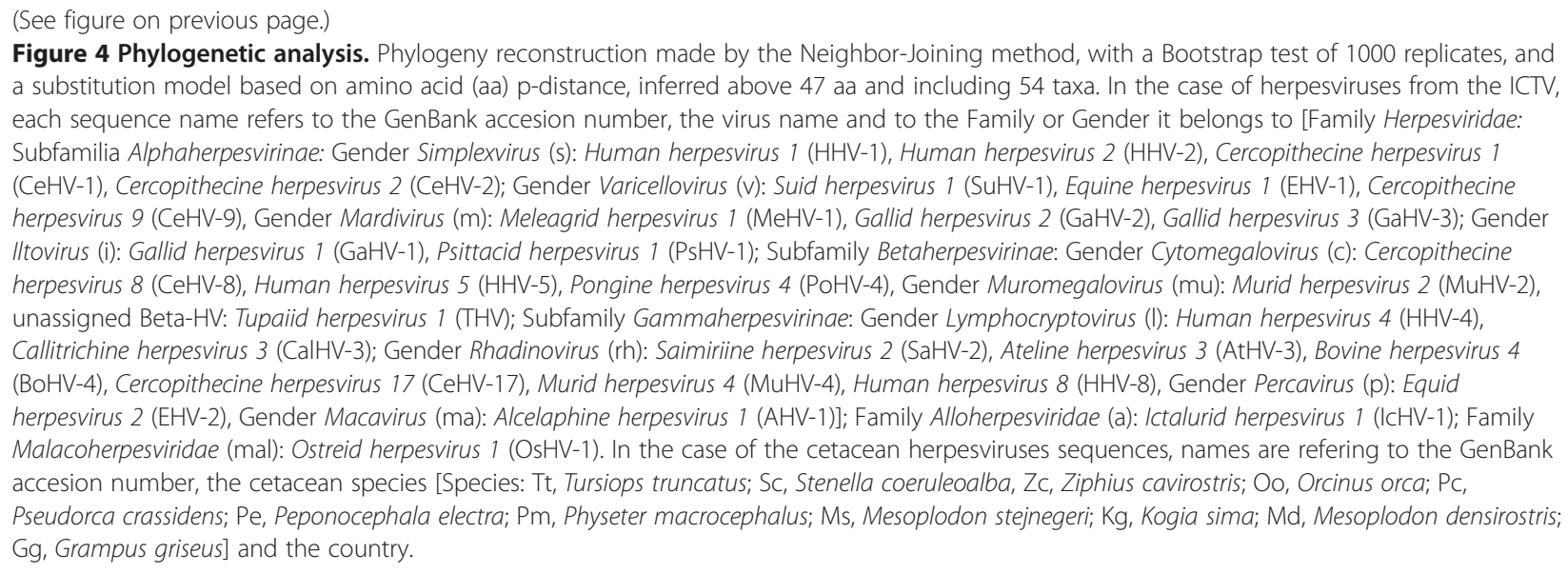

\section{Molecular evaluation}

Direct sequencing was successful for the internal PCR product from the kidney sample. However, cloning was necessary for the internal PCR product from the lung sample and for the external PCR product of the kidney sample. The same 181 bp (60 aa) sequence was obtained from kidney and lung samples, and a 692 bp (230 aa) sequence was obtained from the kidney alone (GenBank accession number JN863234). Phylogenetic analysis (Figure 4) demonstrated that the sequence obtained in this study is a novel HV.

\section{Discussion}

Although in this unique case of stranding the cause of death was not determined, two pathological findings merit consideration. First, a systemic gas embolism was observed similar to that linked to military sonar described in stranded beaked whales [13]. However, it has been determined that no anthropogenic sound source was spatially or temporally used in the area of stranding. Thus, we suggest this kind of gas embolism may be linked to diving problems in "sick", stranded beaked whales (Fernandez, personal communication).

Second, although no gross lesions were observed in the kidneys, two main histopathological findings were noted. Membranous glomerulonephritis, multifocal interstitial aggregate of lymphoplasmacytic cells, multifocal necrotizing tubulointerstitial nephritis and the presence of intranuclear inclusion bodies in epithelial cells were observed.

In terrestrial mammals, interstitial nephritis may be the result of bacterial and viral septicemia, whereby these infectious agents first infect kidney tubules and then induce an inflammatory response in the interstitium [23].

IHC analysis demonstrated HV antigens and EM analysis identified numerous intranuclear HV particles in this case study whale [7].
HV can be ubiquitous and its capacity to cause disease in cetaceans is unclear and may be varied depending upon an individual's condition and species type [7-10]. Recently, systemic herpes viral lesions have been reported in a striped dolphin, probably secondary to immunosuppression caused by morbillivirus co-infection [11].

Tissues from the adult old beaked whale in this study were negative for morbillivirus infection but it had a poor body condition, empty stomach containing small foreign bodies, multiorgan parasitic infestation, chronic adrenalitis and membranous glomerulonephritis. One or more of these conditions/lesions have been described in immunocompromised hosts [23].

Therefore, what is the explanation for an acute viral infection in the tubuloepithelial renal cells associated with chronic lymphoproliferative interstitial nephritis? In dogs, infectious viral canine hepatitis is a well-documented mechanism of interstitial nephritis. Following recovery of dogs from the acute phase and the loss of virus from systemic circulation, virus only reappears in tubular epithelial cells. Thus, virus can persist in the tubular epithelium and cause necrosis as a result of viral-induced cytolysis. This process is followed by lymphoplasmacytic interstitial nephritis [23].

Of particular interest are viral infections in the kidney of immunocompromised human hosts. Epstein Barr virus (EBV) is a ubiquitous HV that can persist in a latent form. B lymphocytes are the usual site of latent infection, whereas epithelial cells usually contain active virus. EBV infection of renal proximal tubular cells may induce cellular immune responses that result in damage to renal interstitium causing interstitial nephritis [24]. The beaked whale in this study presents similarities with viral infections in dogs and humans and provokes questions regarding the prevalence of viral latent infection in cetaceans.

The novel sequence obtained from the kidney of the beaked whale is divergent from previous HV sequences obtained from relative host species of the Ziphiid family: 
From two $\gamma$-HV sequences belonging to the tentatively named Ziphiid herpesvirus 1 (ZiHV-1) [19] found in two $M$. densirostris stranded on the Atlantic coast of the USA (GenBank accession numbers AY803337 and AY949828) $[8,9]$, where both sequences were $100 \%$ identical in a 47 aa region in this study.

From the alpha-HV sequence found in a $M$. densirostris stranded in the eastern Atlantic in 2005 (GenBank accession number GU066291) [7]. As it is unclear whether this sequence belongs to an alpha-HV host specific to the Ziphiid family or to the Delphinidae family, and because almost identical sequences were found in two S. coeruleoalba (Delphinidae family) from the Mediterranean sea (GenBank accession numbers GU068981 and HQ214675) $[11,18]$, no putative virus name has been proposed to date for this $\alpha-\mathrm{HV}$.

From one $\gamma$-HV sequence detected in a Mesoplodon stejnegeri stranded in the Sea of Japan [20] whose putative name, following nomenclature suggested by Maness et al., is "Ziphiid herpesvirus 2" (ZiHV-2).

Thus, following Maness et al., suggested nomenclature, the putative name "Ziphiid herpesvirus 3" (ZiHV-3) has been proposed for the putative novel virus sequence identified in this study (GenBank accession number JN863234).

\section{Conclusions}

Kidney lesions and virus-associated infection have rarely been described in cetaceans. Therefore, data from this case study suggests that the identification of HV infection can be used for the etiological diagnosis of tubulointerstitial and lymphoplasmacytic interstitial nephritis in beaked whales. This conclusion highlights the need for further investigation of other stranded cetaceans that combines pathological and molecular analytical studies. These studies can contribute to a better understanding of $\mathrm{HV}$ infection and disease, using cetaceans as a marine mammal model.

\section{Competing interests}

Authors declare that they have no competing interests.

\section{Authors' contributions}

All authors read and approved the final manuscript.

\section{Acknowledgments}

This work was supported by the Spanish Ministry of Science and Innovation (CGL 2009/12663, CGL 2009/08125) and Canary Islands Science and Technology Program (SolSub C200801000288). We thank Canarias Conservación (Manuel Carrillo) for contributing with Figure 1, and his important collaboration in the Canary Islands Stranding Network.

\section{Author details}

'Unit of Veterinary Histology and Pathology, Institute for Animal Health (IUSA), Veterinary School, University of Las Palmas de Gran Canaria, Canary Islands, Spain. ${ }^{2}$ Research Centre for Animal Health (CISA - INIA), Madrid, Spain.

Received: 29 May 2012 Accepted: 9 November 2012

Published: 13 December 2012

\section{References}

1. Barr B, Dunn JL, Daniel MD, Banford A: Herpes-like viral dermatitis in a beluga whale (Delphinapferus leucas). J Wildl Dis 1989, 25:608-611.

2. Martineau D, Lagaci A, Beland P, Higgins R, Armstrong D, Shugart LR: Pathology of stranded beluga whales (Delphinapterus leucas) from the St. Lawrence estuary, Quebec, Canada. J Comp Pathol 1988, 98:287-311.

3. Kennedy S, Lindstedt IJ, McAliskey MM, McConnell SA, McCullough SJ: Herpesviral encephalitis in a harbor porpoise (Phocoena phocoena). J Zoo Wildl Med 1992, 23:374-379.

4. Van Bressem MF, Van Waerebeek K, Garcia-Godos A, Dekegel D, Pastoret PP: Herpes-like virus in dusky dolphins, Lagenorhynchus obscurus, from coastal Peru. Mar Mamm Sc 1994, 10:354-359.

5. Mikaelian I, Tremblay MP, Montpetit C, Tessaro SV, Cho HJ, House C, Measures L, Martineau D: Seroprevalence of selected viral infections In a population of beluga whales (Delphinapterus leucas) in Canada. Vet Rec 1999, 144:50-51.

6. Blanchard TW, Santiago NT, Lipscomb TP, Garber RL, McFee WE, Knowles S: Two novel alphaherpesviruses associated with fatal disseminated infections in Atlantic bottlenose dolphins. J Wildl Dis 2001, 37:297-305

7. Arbelo M, Sierra E, Esperón F, Watanabe TT, Bellière EN, Espinosa De Los Monteros A, Fernández A: Herpesvirus infection with severe lymphoid necrosis affecting a beaked whale stranded in the Canary Islands. Dis Aquat Organ 2010, 89:261-264.

8. Smolarek Benson KA, Manire CA, Ewing RY, Saliki JT, Townsend Fl, Ehlers B, Romero $\mathrm{CH}$ : Identification of novel alpha and gammaherpesviruses from cutaneous and mucosal lesions of dolphins and whales. J Virol Methods 2006, 136:261-266.

9. Saliki JT, Cooper EJ, Rotstein DS, Caseltine SL, Pabst DA, McLellan WA, Govett P, Harms C, Smolarek KA, Romero CH: A novel gammaherpesvirus associated with genital lesions in a Blainville's beaked whale (Mesoplodon densirostris). J Wildl Dis 2006, 42:142-148.

10. van Elk CE, van de Bildt MWG, de Jong AAW, Osterhaus ADME, Kuiken T: Genital herpesvirus in bottlenose dolphins (Tursiops truncatus): cultivation, epidemiology, and associated pathology. J Wildl Dis 2009, 45:895-906.

11. Soto S, Gonzalez B, Willoughby K, Maley M, Olvera A, Kennedy S, Marco A, Domingo M: Systemic herpesvirus and morbillivirus Co-infection in a striped dolphin (stenella coeruleoalba). J Comp Pathol 2012, 146:269-273.

12. Kelly CJ, Neilson EG: Tubulointerstitial diseases. In The kidney. Edited by Brenner B, Rector F. Philadelphia, PA: W.B. Saunders Co; 1996:1655-1679.

13. Fernández A, Edwards JF, Rodríguez F, Espinosa De Los Monteros A, Herráez P, Castro P, Jaber JR, Martín V, Arbelo M: Gas and fat embolic syndrome involving a mass stranding of beaked whales (family ziphiidae) exposed to anthropogenic sonar signals. Vet Pathol 2005, 42:446-457.

14. Fernández A, Esperón F, Herraéz P, De Los Monteros AE, Clavel C, Bernabé A, Sánchez-Vizcaino JM, Verborgh P, DeStephanis R, Toledano F, Bayón A: Morbillivirus and pilot whale deaths, Mediterranean Sea. Emerg Infect Dis 2008, 14:792-794.

15. Esperon F, Fernandez A, Sanchez-Vizcaino JM: Herpes simplex-like infection in a bottlenose dolphin stranded in the Canary Island. Dis Aquat Organ 2008, 81:73-76.

16. VanDevanter DR, Warrener P, Bennett L, Schultz ER, Coulter S, Garber RL, Rose TM: Detection and analysis of diverse herpesviral species by consensus PCR. J Clin Microbiol 1996, 34:1666-1671.

17. Manire CA, Smolarek KA, Romero CH, Kinsel MJ, Clauss TM, Byrd L: Proliferative dermatitis associated with a novel alphaherpesvirus in an Atlantic bottlenose dolphin (Tursiops truncatus). J Zoo Wildl Med 2006, 37:174-181.

18. Bellière EN, Esperón F, Arbelo M, Muñoz MJ, Fernández A, Sánchez-Vizcaíno $J M$ : Presence of herpesvirus in striped dolphins stranded during the cetacean morbillivirus epizootic along the Mediterranean Spanish coast in 2007. Arch Virol 2010, 155:1307-1311.

19. Maness HT, Nollens HH, Jensen ED, Goldstein T, LaMere S, Childress A, Sykes J, St Leger J, Lacave G, Latson FE, Wellehan JF Jr: Phylogenetic analysis of marine mammal herpesviruses. Vet Microbio/ 2011, 149:23-29.

20. Miyoshi K, Nishida S, Sone E, Tajima Y, Makara M, Yoshioka M, Nakamura M, Yamada TK, Koike H: Molecular identification of novel alpha- and gammaherpesviruses from cetaceans stranded on Japanese coasts. Zoolog Sci 2011, 28:126-133.

21. McGeoch DJ, Rixon FJ, Davison AJ: Topics in herpesvirus genomics and evolution. Virus Res 2006, 117:90-104. 
22. International committee on taxonomy of viruses, UK (ICTV). 2002

[http://www.ictvdb.rothamsted.ac.uk/lctv/index.htm]

23. Confer A, Panciera RJ: The urinary system. In Thomson's special veterinary pathology. 3rd edition. Edited by McGavin MD, Carlton WW, Zachary JF. Mosby. St: Louis. Missouri; 2001:235-278.

24. Becker JL, Miller F, Nuovo GJ, Josepovitz C, Schubach WH, Nord EP: Epstein-Barr virus infection of renal proximal tubule cells: possible role in chronic interstitial nephritis. J Clin Invest 1999, 104:1673-1681.

doi:10.1186/1746-6148-8-243

Cite this article as: Arbelo et al.: Herpes virus infection associated with interstitial nephritis in a beaked whale (Mesoplodon densirostris). BMC Veterinary Research 2012 8:243.

\section{Submit your next manuscript to BioMed Central and take full advantage of:}

- Convenient online submission

- Thorough peer review

- No space constraints or color figure charges

- Immediate publication on acceptance

- Inclusion in PubMed, CAS, Scopus and Google Scholar

- Research which is freely available for redistribution 